\title{
Safety and effectiveness of vascular endoprosthesis for malignant superior vena cava syndrome
}

\author{
N P Nguyen, ${ }^{1}$ T L Borok, ${ }^{2}$ J Welsh, ${ }^{1}$ V Vinh-Hung ${ }^{3}$
}

${ }^{1}$ Department of Radiation Oncology, University of Arizona, Tucson, Arizona, USA;

${ }^{2}$ Radiation Oncology Service, Thomas Louis Borok M.D. P.A. Dallas, Texas, USA; ${ }^{3}$ Oncology Centre, Academic Hospital VUB, Jette, Belgium

Correspondence to:

Dr N P Nguyen, University of Arizona, Department of Radiation Oncology, N Campbell Ave, P0 Box 245081, Tucson, AZ 85724-5081, USA NamPhong.Nguyen@ yahoo.com

Received 20 June 2007 Revised 24 October 2007 Accepted 26 October 2007

\section{ABSTRACT}

Background: Superior vena cava syndrome management has been traditionally radiation therapy, chemotherapy or chemoradiation, depending on the underlying malignancy involved and individual clinicopathological features of the case. Recent emergence of endovascular stents offer the opportunity for immediate relief of the venous stenosis. This review examines findings from the published series which used endovascular prosthesis for this syndrome with regards to efficacy and safety.

Methods: Literature search identified studies using endovascular stents as initial therapy or for recurrence of malignant superior vena cava syndrome. Effectiveness and toxicity from stent placement was assessed.

Results: Endovascular stent placement provides immediate haemodynamic relief of venous compression either before or after definitive therapy in the majority of cancer patients. Severe bleedings, cardiopulmonary complications and stent migrations remain significant problems for patient management.

Conclusions: Endovascular prosthesis is an effective modality for malignant superior vena cava syndrome with acceptable morbidity. Prospective studies should be performed to determine the optimal anticoagulation regimen.

The pathology of superior vena cava syndrome (SVCS) is frequently secondary to external compression of the superior vena cava (SVC) because of the low internal venous pressure situated within rigid structures of the thorax (trachea, right bronchus, aorta, perihilar and para-aorta lymph nodes). ${ }^{1}$ SVC compression induces venous hypertension responsible for SVCS clinical manifestations (neck and/or arm oedema, respiratory distress, cyanosis and obtundation). Although rarely fatal, these haemodynamic effects cause serious distress when the stenosis is severe. ${ }^{2}$ SVCS aetiology is predominantly malignant with lung cancer as the primary cause. ${ }^{3}$ As a result, radiation therapy, chemotherapy or chemoradiation are the main traditional therapies. ${ }^{4}{ }^{5}$ SVCS recurrence may occur after successful primary therapy for tumour recurrence. ${ }^{6}$ Thus alternative salvage treatment is needed for palliation. Since 1986, endovascular stent placement offered an effective therapy to relieve venous compression when primary therapy failed or at the time of cancer diagnosis. ${ }^{7-10}$ Endovascular stent popularity increased because of fast relief of the venous congestion, ${ }^{11}{ }^{12}$ but report of fatal complications ${ }^{8}$ have tempered the initial enthusiasm and have prompted us to conduct this survey assessing effectiveness and safety of this interventional modality.

\section{METHODS}

This systematic review was designed to investigate the safety and efficacy of endovascular stents for the treatment of malignant SVCS. A search was undertaken from 1986, when the stent was first reported to relieve malignant SVCS, until 2007. The search was based on PubMed electronic databases. The following terms were explored and used for each database search: superior vena cava syndrome, malignant and endovascular stent. Reference lists of relevant papers were then searched for additional publications. The papers were classified into two categories: effectiveness of the stent at diagnosis of SVC or after failure of the primary therapy. The following criteria were analysed in each article: definition of the stent success, rate of re-occlusion, mortality rate, major complications and protocol for anticoagulation following stent placement.

\section{Overview of stent placement protocol as reported by the literature}

The severity and location of the venous stenosis were confirmed by venography under local anaesthesia. Patients were monitored for oxygen saturation, blood pressure and cardiac function during the procedure. The stents were usually introduced through the common femoral veins but the brachial venous route could also be used if the guidewire could not cross the stenosis through the femoral route. Following placement of the stent, a final SVC cavogram confirmed patency of the stent. Most institutions recommended anticoagulation following stent placement but the type and duration of anticoagulation therapy varied depending on the institution. Patients were assessed for resolution of their clinical symptoms. Chest $x$ ray was usually performed following the procedure to verify location of the stent (possible stent migration) and the degree of stent expansion. Unless the SVCS recurred, venograms were not routinely repeated. Clinical patency, recurrence of SVCS and complication rates following the procedure were reported

\section{Types of endovascular stents}

Many endovascular stents are available to relieve the stenosis. ${ }^{91-21}$ The stents come in a variety of sizes and lengths. The endoprosthesis is released across the localised site of obstruction, spanning from above and below the stricture to prevent re-occlusion. ${ }^{12}$ Stents may be classified into two categories: selfexpanding stents and balloon expanding stents. Once released, self-expanding stents (Gianturco-Z stent, Wallstent, Memotherm) $)^{11} 131821$ continuously push radially outward against the stenosis until they reach 
Table 1 Guidelines that may influence the choice of a specific type of stent for the treatment of superior vena cava syndrome

\begin{tabular}{ll}
\hline Stent & Characteristics of the stenosis \\
\hline Gianturco Z-stent & $\begin{array}{l}\text { Short, straight stenosis involving large } \\
\text { diameter vessel. }\end{array}$ \\
Wallstent and Memotherm stent & $\begin{array}{l}\text { Long, curved stenosis involving vessel } \\
\text { with smaller diameter. }\end{array}$ \\
Palmaz stent & $\begin{array}{l}\text { Short stenosis in locations where stent } \\
\text { migration may pose a problem. }\end{array}$ \\
\hline
\end{tabular}

their initial size. Thus self-expanding stents may perforate the vessel wall and cause complications.

Balloon expanding stents (Palmaz and Strecker stent) ${ }^{15}$ are mounted on a balloon on the end of the delivery catheter. When the stent is positioned within the stenosis, the balloon is inflated, causing the stent to expand to a desired diameter, and is less likely to cause perforation. Balloon expanding stents have a high radial force when inflated. However, once expanded, their compressibility may lead to re-occlusion of the vessels or stent fracture. The two types of stents can be combined when there is residual stenosis after stent placement. For example, a balloon expanding stent can be placed within a self-expanding stent to maintain stent patency. ${ }^{18}$

The Gianturco-Z stent (Z-stent) was most frequently used in the first reports. ${ }^{714^{17}}$ It is the most rigid stent with a large diameter (up to $3 \mathrm{~cm}$ ), excellent radial expansile strength and is commonly used in large diameter vessels. The open structure of the stent does not cause obstruction to the collateral side vessels bridged by the stent. Because of its short length, large diameter and rigidity, multiple insertions of the Z-stent for long stenosis may represent a technical challenge, especially along the curvature. The wide gap between stent wires may allow tumour ingrowth through the stent and re-stenosis.

The Wallstent is flexible, long and easy to insert. ${ }^{11}{ }^{19}{ }^{20}$ It has a smaller diameter (up to $1.6 \mathrm{~cm}$ ) and less radial strength, and is best suited for smaller vessels such as brachiocephalic vein stenosis or along curvatures. Its mesh-like structure prevents infiltration of the tumour through the stent.

Wallstent has become more popular because of its length and ease of insertion. Once deployed, Wallstent does foreshorten by $20 \%$.
Memotherm stent ${ }^{9}$ is also flexible as it is constructed of a tight mesh of nitinol (nickel-titanium compound) with superelasticity, allowing the stent to expand to its initial size without any shortening of the length. It is best suited for stenosis along curvatures, the same as the Wallstent.

Palmaz stent is rigid $^{15} 18$ and requires balloon assistance to distend it. It has excellent radial force but will not expand beyond the limits of the specific balloon size inflated. Its short length makes it most effective in short segmental stenosis. Advantages include ease of targeting the site of stent expansion, control of degree of stent expansion and a decreased chance of migration once released. However, because of its compressibility, vessel re-stenosis and stent fracture may occur.

Other prosthesis such as the Strecker or Symphony are of limited use because of the small diameter (up to $12 \mathrm{~mm}$ ) but have been reported to be successful for treatment of SVCS. ${ }^{13} 16$

The specific type of stent selected for use is determined by the characteristics of the stenosis (diameter, length and location) and the experience of the interventional radiologist. Table 1 summarises some of the criteria that may influence stent choice.

\section{Haemodynamic changes following stent placement}

Sudden venous lumen diameter increase reverses aberrant caval pressure distal to the pathological stenosis and improves right atrial pressure from restored venous return. Pulmonary capillary wedge pressure and cardiac output immediately increase following successful stent placement. ${ }^{17}$ Acute pulmonary oedema, which may be fatal, ${ }^{18}$ can occur in individuals with comorbid underlying coronary artery disease and heart failure. Clinical manifestations of SVCS resolve within 24-48 h postendovascular stent placement. Endothelial intima usually covers stents and incorporates them into the physiological vascular system within a few weeks time following stent placement.' During this "intimasation/vascularisation period", the patient remains at highest risk for thrombotic events. Anticoagulation is recommended following stent placement but optimal duration and methods of anticoagulation therapy remain controversial. ${ }^{13-16}$ Sometimes anticoagulation is not given either before or after completion of stent placement. ${ }^{16}$ Thrombolytic therapy is usually recommended if SVC thrombosis is found prestenting. ${ }^{510} 11$ Thrombolysis and anticoagulation may induce

Table 2 Effectiveness of the Wallstent endoprosthesis in relieving malignant superior vena cava obstruction following failure of primary therapy

\begin{tabular}{|c|c|c|c|c|c|c|}
\hline Study & $\begin{array}{l}\text { Patient } \\
\text { No }\end{array}$ & $\begin{array}{l}\text { Prior } \\
\text { therapy }\end{array}$ & $\begin{array}{l}\text { Patient } \\
\text { with lung } \\
\text { cancer }\end{array}$ & $\begin{array}{l}\text { Effectiveness } \\
\text { (\%) }\end{array}$ & $\begin{array}{l}\text { Recurrence } \\
\text { (\%) }\end{array}$ & $\begin{array}{l}\text { Follow-up } \\
\text { (months) }\end{array}$ \\
\hline Monaco $^{19}$ & 40 & $\begin{array}{l}\text { RT (33) } \\
\text { C (33) }\end{array}$ & 32 & 90 & 4 & 6 \\
\hline Stock ${ }^{22}$ & 14 & $\begin{array}{l}\text { RT (5) } \\
C(4)\end{array}$ & 12 & 83 & 25 & 3 \\
\hline Dinkel $^{23}$ & 84 & $\begin{array}{l}\text { RT (28) } \\
\text { C (54) }\end{array}$ & 73 & 99 & 22 & NS \\
\hline $\mathrm{Kim}^{25}$ & 10 & $\begin{array}{l}\mathrm{RT}(6) \\
\mathrm{C}(2)\end{array}$ & 10 & 100 & 20 & 6.7 \\
\hline Dyet $^{26}$ & 17 & RT (14) & 12 & 100 & 12 & NS \\
\hline Courtheoux ${ }^{27}$ & 20 & $\begin{array}{l}\text { RT (10) } \\
\text { C (19) }\end{array}$ & 16 & 95 & 15 & NS \\
\hline Nicholson ${ }^{28}$ & 76 & $\begin{array}{l}\text { RT (NS) } \\
\text { C (NS) }\end{array}$ & 58 & 100 & 9.8 & NS \\
\hline Hennequin $^{29}$ & 15 & $\begin{array}{l}\text { RT (6) } \\
\text { C (13) }\end{array}$ & 13 & 93 & 0 & 3 \\
\hline
\end{tabular}

C, chemotherapy; NS, not specified; RT, radiotherapy. 
Table 3 Effectiveness of the Gianturco and other types of endoprosthesis to relieve obstruction from malignant superior vena cava syndrome following failure of primary therapy

\begin{tabular}{|c|c|c|c|c|c|c|c|}
\hline Study & $\begin{array}{l}\text { Patient } \\
\text { No }\end{array}$ & $\begin{array}{l}\text { Prosthesis } \\
\text { type }\end{array}$ & $\begin{array}{l}\text { Treatment } \\
\text { type }\end{array}$ & $\begin{array}{l}\text { Lung } \\
\text { cancer }\end{array}$ & $\begin{array}{l}\text { Effectiveness } \\
(\%)\end{array}$ & $\begin{array}{l}\text { Recurrence } \\
(\%)\end{array}$ & $\begin{array}{l}\begin{array}{l}\text { Follow-up } \\
\text { (months) }\end{array}\end{array}$ \\
\hline Crowe $^{10}$ & 13 & $\begin{array}{l}G(9) \\
W(1) \\
P(1)\end{array}$ & $\begin{array}{l}\text { RT (10) } \\
\text { C (1) }\end{array}$ & 11 & 91 & 41 & 35 \\
\hline Marcy $^{13}$ & 37 & $\begin{array}{l}\text { G (29) } \\
S(5) \\
M(5)\end{array}$ & NS & 28 & 97 & 8 & 6 \\
\hline Elson ${ }^{15}$ & 5 & $P$ & RT (4) & 5 & 100 & 0 & 3 \\
\hline $\mathrm{Kee}^{18}$ & 43 & $\begin{array}{l}P(N S) \\
W(N S)\end{array}$ & $\begin{array}{l}\text { RT }(30) \\
C(6)\end{array}$ & 22 & 97 & 11 & 7 \\
\hline Greillier $^{21}$ & 8 & $\begin{array}{l}M \text { (NS) } \\
A(N S)\end{array}$ & $\begin{array}{l}\text { RT (2) } \\
C(6)\end{array}$ & 8 & 100 & 33 & NS \\
\hline Tanigawa $^{30}$ & 23 & G & $\begin{array}{l}\text { RT (11) } \\
\text { C (1) }\end{array}$ & 19 & 78 & 0 & 3 \\
\hline $\operatorname{Tan}^{31}$ & 11 & $\begin{array}{l}G(10) \\
S(1)\end{array}$ & $\begin{array}{l}\text { RT or } \\
\mathrm{C}(7)\end{array}$ & 11 & 100 & 18 & 3.9 \\
\hline Furui $^{32}$ & 16 & G & $\begin{array}{l}\text { RT (7) } \\
\text { C (3) }\end{array}$ & 14 & 81 & 25 & 2.9 \\
\hline Gaines $^{33}$ & 20 & G & $\begin{array}{l}\text { RT (11) } \\
\text { C (5) } \\
\text { Su (6) }\end{array}$ & 15 & 90 & 25 & NS \\
\hline Oudkerk ${ }^{34}$ & 30 & $\begin{array}{l}\text { G (17) } \\
\text { W (13) }\end{array}$ & $\begin{array}{l}\text { RT (22) } \\
C(12)\end{array}$ & 20 & 96 & 23 & 2.5 \\
\hline
\end{tabular}

A, Angiomed stent; C, chemotherapy; G, Gianturco stent; M, Memotherm stent; NS, not specified; P, Palmaz stent; RT, radiotherapy; S, Strecker stent; Su, surgery; W, Wallstent stent.

severe bleeding following endovascular stent placement and result in reported mortalities. ${ }^{19} 20$

\section{Stent effectiveness after primary therapy failure}

Most endovascular prostheses salvage studies for recurrent SVCS report effective relief of the venous compression after cancer recurrence. ${ }^{22-24}$ The majority of these patients had lung cancer ${ }^{25-27}$ and were treated with either chemotherapy or radiotherapy. As a result, prognosis was very poor as stents were used late in their clinical course, primarily for palliation of severe symptoms. Mean and median follow-up ranged from 2 to 7 months. Stents provided rapid symptomatic improvement as early as a few hours after the placement. ${ }^{28}$ Stent effectiveness ranged from $81 \%$ to $100 \%$ and was unrelated to stent type. Wallstent effectiveness ranged from $90 \%$ to $100 \%{ }^{19} 222325-29$ Other stent types had 78$100 \%$ success rates in relieving the venous stenosis. ${ }^{15}{ }^{30-33}$ Reports for multiple stents used within the same institution achieved similar results. ${ }^{10} 1315182134$ Thus the experience of the interventional radiologist is the key to achieving good results. Reobstruction rates ranged from $0 \%$ to $33 \%$. ${ }^{19} 21-2325-33$

Secondary SVCS recurrence following initial successful primary therapy is attributed to venous thrombosis or vessel tumour invasion. ${ }^{19} 20{ }^{32}$ It is difficult to determine the status of optimum anticoagulant therapy post-stent placement because this policy differed among reporting institutions.

Secondary stent re-stenosis may be resolved with further stenting. ${ }^{18}$ Tables 2 and 3 summarise the effectiveness of the Wallstent prosthesis and other types of stents, respectively, for malignant SVCS following failure of primary therapy.

\section{Stent effectiveness for treatment of malignant SVCS at initial presentation}

Although endovascular stents are traditionally offered to salvage recurrent SVCS after primary therapy failure, vascular

Table 4 Effectiveness of endovascular prosthesis in relieving obstruction at diagnosis of malignant superior vena cava syndrome prior to primary therapy

\begin{tabular}{|c|c|c|c|c|c|c|c|}
\hline Study & $\begin{array}{l}\text { Patient } \\
\text { No }\end{array}$ & $\begin{array}{l}\text { Prosthesis } \\
\text { type }\end{array}$ & $\begin{array}{l}\text { Treatment } \\
\text { after stent }\end{array}$ & $\begin{array}{l}\text { Lung } \\
\text { cancer }\end{array}$ & $\begin{array}{l}\text { Effectiveness } \\
(\%)\end{array}$ & $\begin{array}{l}\text { Recurrence } \\
(\%)\end{array}$ & $\begin{array}{l}\text { Follow-up } \\
\text { (months) }\end{array}$ \\
\hline Chatziioannou $^{9}$ & 18 & $\mathrm{M}$ & RT (18) & 15 & 100 & 0 & NS \\
\hline \multirow[t]{2}{*}{ Biedrager $^{16}$} & 17 & $S$ & RT (4) & 11 & 88 & 0 & 5 \\
\hline & & & $C(10)$ & & & & \\
\hline \multirow[t]{2}{*}{ Gross $^{24}$} & 13 & W & RT (11) & 11 & 100 & 0 & 3 \\
\hline & & & $C(6)$ & & & & \\
\hline \multirow[t]{3}{*}{ Lanciego $^{35}$} & 52 & W & RT (2) & 49 & 100 & 11 & 6.4 \\
\hline & & & $C(22)$ & & & & \\
\hline & & & $\mathrm{RT}+\mathrm{C}(12)$ & & & & \\
\hline \multirow[t]{2}{*}{ Lopez-Muniz $^{36}$} & 16 & W & RT (NS) & 12 & 100 & 18 & NS \\
\hline & & & C (NS) & & & & \\
\hline Nagata $^{37}$ & 71 & Z & RT or C (30) & 58 & 87 & 7 & 5.4 \\
\hline
\end{tabular}

C, chemotherapy; M, Memotherm stent; NS, not specified; RT, radiotherapy; S, Symphony stent; W, Wallstent; Z, Gianturco stent. 
Table 5 Fatal complications rate following endovascular stent placement for malignant SVCS

\begin{tabular}{|c|c|c|c|}
\hline Study & Death & Cause of death & Other complications \\
\hline Wilson $^{8}$ & $1 / 18$ & Not specified & \\
\hline Crowe $^{10}$ & $1 / 12$ & Cardiac arrest & 2 haematemesis \\
\hline Thony $^{11}$ & $1 / 26$ & Haemorrhage & $\begin{array}{l}1 \text { pneumonia, } \\
1 \text { infection of venous } \\
\text { line }\end{array}$ \\
\hline $\mathrm{Kee}^{18}$ & $2 / 43$ & $\begin{array}{l}\text { Respiratory failure (1), } \\
\text { pulmonary embolism (1) }\end{array}$ & $\begin{array}{l}1 \text { stent migration, } \\
1 \text { gastrointestinal } \\
\text { haemorrhage }\end{array}$ \\
\hline Monaco $^{19}$ & $3 / 40$ & $\begin{array}{l}\text { Haemoptysis }(1) \text {, pulmonary } \\
\text { oedema (1), respiratory } \\
\text { failure (1) }\end{array}$ & \\
\hline Urruticoechea $^{20}$ & $1 / 52$ & Lung haemorrhage & $\begin{array}{l}1 \text { stent migration, } \\
1 \text { cardiac arrhythmia, } \\
1 \text { sepsis }\end{array}$ \\
\hline Stock $^{22}$ & $1 / 14$ & Not specified & \\
\hline Dinkel $^{23}$ & $1 / 84$ & Cardiac tamponade (1) & \\
\hline Gross $^{24}$ & $1 / 13$ & Cardiac arrhythmia & \\
\hline Dyet $^{26}$ & $1 / 17$ & Cerebral haemorrhage & \\
\hline Courtheoux ${ }^{27}$ & $1 / 20$ & Myocardial infarction & \\
\hline Nicholson ${ }^{28}$ & $1 / 76$ & Brain haemorrhage & $\begin{array}{l}1 \text { groin haematoma, } \\
1 \text { DVT }\end{array}$ \\
\hline Gaines $^{33}$ & $1 / 20$ & Haemoptysis & \\
\hline Oudkerk ${ }^{34}$ & $1 / 30$ & Haemoptysis & \\
\hline
\end{tabular}

prosthesis is now considered firstline therapy in an increasing number of institutions because of device efficacy in relieving patient symptoms. ${ }^{9} 16$ 24 35-37 Rapid relief of the venous compression allows early cisplatin based chemotherapy initiation for small cell lung cancer and metastatic non-small cell carcinomas which require hydration. Selected studies show almost all patients achieved immediate relief of the venous congestion allowing underlying aetiology specific therapy to be initiated. ${ }^{9} 2437$ SVCS recurrence still occurs up to $18 \%$, despite anticoagulation. ${ }^{35}{ }^{36}$ Short term clinical follow-up in these studies limits survival analysis; it remains to be reported if this new approach will be affiliated with improved survivals. Table 4 summarises the effectiveness of various stent types for the treatment of SVCS prior to definitive antineoplastic therapy.

\section{Complication rate following stent placement}

In 32 studies, $^{8-39} 17$ deaths occurred (2\%) during or shortly after 884 malignant SVCS stent placements. Seven of the 17 deaths (41\%) were attributed to severe haemorrhage: two cerebral, three pulmonary and two unspecified sites. Four of 17 deaths $(23 \%)$ were attributed to cardiac events: two arrhythmia, one myocardial infarction and one tamponade. Three of 17 deaths (17\%) were attributed to respiratory failure.

Cause of death was unattributed in two cases $(12 \%)$; one death $(6 \%)$ was documented pulmonary embolism.

Only 38 of 884 (4\%) patients experienced major complications attributed to caval stenting, and these were most commonly stent migration or poor stent positioning $(n=18)$ followed by bleeding $(n=8)$, infection $(n=2)$, deep venous thrombosis $(n=4)$, pulmonary oedema $(n=3)$, cardiac arrhythmia $(n=2)$ and pulmonary embolism $(n=1)$.

Fatal haemorrhages reported were generally attributed to thrombolytic agent administration, including streptokinase, urokinase and tissue plasminogen activator to dissolve intracaval clot prior to vascular prosthesis insertion. Occult cerebral metastases may also explain brain haemorrhage during fibrinogen lysis. $^{28}$ Massive haemoptysis may also occur during thrombolytic therapy ${ }^{34}$ or during maintenance anticoagulation
Table 6 Non-fatal complications resulting from endovascular stent placement for malignant vena cava syndrome

\begin{tabular}{lll}
\hline Study & Type of complications & $\begin{array}{l}\text { Complication } \\
\text { rate }\end{array}$ \\
\hline $\begin{array}{l}\text { Chatziioannou } \\
\text { Marcy }\end{array}$ & 1 stent migration & $1 / 18(5 \%)$ \\
Biedrager $^{16}$ & 2 pulmonary oedema & $2 / 37(5 \%)$ \\
& 1 stent migration & $2 / 17(11 \%)$ \\
Greillier $^{21}$ & 1 cardiac arrhythmia & \\
& 1 haemorrhage & $3 / 8(37 \%)$ \\
Hennequin $^{29}$ & 2 thrombosis & \\
Tanigawa $^{30}$ & 1 retroperitoneal haematoma & $1 / 15(6 \%)$ \\
Tan $^{31}$ & 1 phlebitis & $1 / 23(4 \%)$ \\
Furuij $^{32}$ & 2 stent migration & $3 / 11(27 \%)$ \\
Gaines $^{33}$ & 1 haemorrhage of femoral puncture & \\
Lopez-Muniz $^{36}$ & 4 stent migration & $4 / 16(25 \%)$ \\
Lanciego $^{35}$ & 1 haemoptysis & $1 / 20(5 \%)$ \\
Nagata $^{37}$ & 2 stent migration & $2 / 16(12 \%)$ \\
Kishis $^{38}$ & 1 stent migration & $2 / 52(3 \%)$ \\
\hline
\end{tabular}

therapy. ${ }^{20}$ Paraneoplastic hypercoagulation state combined with the presence of a foreign body increased the risk of thrombosis after stent placement. However, parameters for optimal anticoagulation therapy have not been determined. Some authors advocated no antithrombotic therapy post-stenting, ${ }^{16}$ but most reported studies recommended prolonged anticoagulation, including heparin, warfarin and antiplatelet agents. ${ }^{9-15}$ 17-36

As a result, extremes of haemorrhage versus venous thrombosis attributed to excessive versus inadequate anticoagulation remains a significant problem during follow-up in reported studies. $^{21293133}$

Endovascular stent placement also exposes patients to significant cardiopulmonary complication risks. Most malignancies were bronchogenic carcinoma and most patients had underlying comorbid coronary artery disease attributed to smoking and age. Stenting promptly dilatated SVC diameter and increased venous return and pulmonary wedge pressure. Comorbid factors, such as borderline cardiac function, arrhythmias, pulmonary oedema, myocardial infarction and respiratory failure predisposed patients to an adverse outcome. ${ }^{101316192427}$ Close haemodynamic monitoring during stenting may prevent or mitigate these types of complications. ${ }^{17} 38$

Stent migration or malposition remains a significant long term complication and is occasionally fatal, ${ }^{23}$ although most stent migrations did not result in long term morbidity. ${ }^{9} 163132$ 35-37 Migration/malposition likely decreases as the experience of the interventional radiologist increases. Tables 5 and 6 summarise fatal and non-fatal complications following stent placement for malignant SVCS.

\section{CONCLUSIONS}

Endovascular stent placement provides fast and effective relief of the vascular stenosis associated with malignant SVCS with acceptable morbidity. Patient management requires careful haemodynamic and coagulation profile monitoring of the patient both during and after stenting. Prospective studies are needed to address optimal anticoagulation therapy pre-stent preparation and post-stent follow-up as patients remain at risk for thrombosis as well as haemorrhagic death. 
Acknowledgements: The authors would like to thank Roberta Weiss for the preparation of this manuscript

Competing interests: None.

\section{REFERENCES}

1. Lochridge S, Knibbbe W, Doty D. Obstruction of superior vena cava. Surgery 1979;85:14-24

2. Gauden SJ. Superior vena cava syndrome induced by bronchogenic carcinoma: is this an oncological emergency? Australas Radiol 1993;37:363-6.

3. Reechaipichitkul W, Thongpaen S. Etiology and outcome of superior vena cava obstruction in adults. Southeast Asian Trop Med Public Health 2004;35:453-7.

4. Armstrong BA, Perez CA, Simpson JR, et al. Role of irradiation in the management of superior vena cava syndrome. Int J Radiat Oncol Biol Phys 1987;13:531-9.

5. Yellin A, Mandel M, Gechavi G, et al. Superior vena cava syndrome associated with lymphoma. Am J Dis Child 1992;146:1060-3.

6. Mose S, Stabik C, Eberlein K, et al. Retrospective analysis of the superior vena cava syndrome in irradiated cancer patients. Anticancer Res 2006;26:4933-6.

7. Charnsangavej $\mathbf{C}$, Carrasco $C$, Wallace $S$, et al. Stenosis of the vena cava: preliminary assessment of treatment with expandable metallic stents. Radiology 1986;161:295-8.

8. Wilson $\mathbf{E}$, Lyn E, Lynn A, et al. Radiological stenting provides effective palliation in malignant central venous obstruction. Clin Oncol 2002;14:228-32.

9. Chatziioannou A, Alexopoulos T, Mourikis D, et al. Stent therapy for malignant superior vena cava syndrome: Should be first line therapy or simple adjunct to radiotherapy. Eur J Radiol 2003;47:247-50.

10. Crowe MTI, Davies $\mathrm{CH}$, Gaines PA. Percutaneous management of superior vena cava occlusions. Cardiovasc Interv Radiol 1995;18:367-72.

11. Thony $\mathbf{F}$, Moro D, Witmeyer $P$, et al. Endovascular treatment of superior vena cava obstruction in patients with malignancies. Eur Radiol 1999:9:965-71.

12. Shah R, Sabanathan S, Lowe RA, et al. Stenting in malignant obstruction of superior vena cava. J Thorax Cardiovasc Surg 1996;112:335-40.

13. Marcy PY, Magne N, Bentolila F, et al. Superior vena cava obstruction: is stenting necessary. Support Care Cancer 2001;9:103-7.

14. Rosch J, Uchida BT, Hall LD, et al. Gianturco-Rosch expandable Z-stents in the treatment of superior vena cava syndrome. Cardiovas Interv Radiol 1992;15:319-27.

15. Elson JD, Becker GJ, Wholey MH, et al. Vena cava and central venous stenosis: management with Palmaz-balloon-expandable intraluminal stents. J Vasc Interv Radiol 1991:2:215-13.

16. Bierdrager $\mathbf{E}$, Lampmann LEH, Lohle PNM, et al. Endovascular stenting in neoplastic superior vena cava syndrome prior to chemotherapy or radiotherapy. Neth $\mathrm{J}$ Med 2005:63:20-3.

17. Yamagami T, Nakamura $T$, Kato $T$, et al. Hemodynamic changes after self expandable metallic stent therapy for superior vena cava syndrome. AJR Am J Roentgenol 2002;178:635-9

18. Kee ST, Kinoshita L, Razavi MK, et al. Superior vena cava syndrome: Treatment with catheter directed thrombolysis and endovascular stent placement. Radiology 1998;206:187-93.

19. Monaco RG, Bertoni H, Pallota G, et al. Use of self-expanding vascular endoprosthesis in superior vena cava syndrome. Eur J Cardiothorac Surg 2003;24:208-11.
20. Urruticoechea A, Mesia R, Dominguez J, et al. Treatment of malignant superior vena cava syndrome by endovascular stent insertion. Experience on 52 patients with lung cancer. Lung Cancer 2004;43:209-14.

21. Greillier L, Barlesi F, Doddoli C, et al. Vascular stenting for palliation of superior vena cava obstruction in non-small cell lung cancer patients: a future standard procedure? Respiration 2004;71:178-83.

22. Stock KW, Jacob AL, Proske $\mathrm{M}$, et al. Treatment of malignant obstruction of the superior vena cava with the self Expanding Wallstent. Thorax 1995;50:1151-6.

23. Dinkel HP, Mettke B, Schmid F, et al. Endovascular treatment of malignant superior vena cava syndrome: Is bilateral Wallstent placement superior to unilateral placement. J Endovasc Ther 2003;10:788-97.

24. Gross CM, Kramer J, Waigand J, et al. Stent implantation in patients with the superior vena cava syndrome. AJR Am J Roentgenol 1997;169:429-32.

25. Kim YI, Kim KS, Ko YC, et al. Endovascular stenting as a first choice for palliation of superior vena cava syndrome. J Korean Med Sci 2004;19:519-22.

26. Dyet JF, Nicholson A, Cook AM. The use of the Wallstent endovascular prosthesis in the treatment of malignant obstruction of the superior vena cava. Clin Radiol 1993;48:381-5.

27. Courtheoux $\mathbf{P}$, Alkofer $B$, Refai $M A$, et al. Stent placement in superior vena cava syndrome. Ann Thorac Surg 2003:75:158-61.

28. Nicholson AA, Duncan EF, Anthony A, et al. Treatment of malignant superior vena cava obstruction: metal stents or radiation therapy. J Vasc Int Radiol 1997:8:781-8.

29. Hennequin LM, Fade 0, Fays JG, et al. Superior vena cava stent placement: Results with the Wallstent endoprosthesis. Radiology 1995;196:353-61.

30. Tanigawa N, Sawada S, Mishima K, et al. Clinical outcome of stenting in superior vena cava syndrome associated with malignant tumors. Acta Radiol 1998;39:669-74.

31. Tan BS, Htoo MM, Yeong KY. The use of metallic stents in the treatment of malignant superior vena cava obstruction. Ann Acad Med Singapore 1995;24:198-203

32. Furui S, Sawada S, Kuramoto K, et al. Gianturco stent placement in malignant caval obstruction: analysis of factors for predicting the outcome. Radiology 1995;195:147-52.

33. Gaines PA, Belli AM, Anderson PB, et al. Superior vena caval obstruction managed by the Gianturco Z stent. Clin Radiol 1994;49:202-8.

34. Oudkerk M, Kuijpers TJA, Schmitz PIM, et al. Self-expanding metal stents for palliative treatment of superior vena cava syndrome. Cardiovasc Int Radiol 1996;19:146-51.

35. Lanciego C, Chacon JL, Julian A, et al. Stenting as first option for endovascular treatment of malignant superior vena cava syndrome. AJR Am J Roentgenol 2001;177:585-93.

36. Lopez-Muniz JIC, Garcia GL, Lanciego PC, et al. Treatment of superior and inferior vena cava syndrome of malignant cause with Wallstent catheter placed percutaneously. Am J Clin Oncol 1997;20:293-7.

37. Nagata T, Makutani S, Uchida $\mathrm{H}$, et al. Follow-up results of 71 patients undergoing metallic stent placement for the treatment of a malignant obstruction of the superior vena cava. Cardiovasc Int Radiol 2007;30:959-67.

38. Kishi K, Sonomura T, Mitsuzane K, et al. Self-expandable metallic stent therapy for superior vena cava syndrome: clinical observations. Radiology 1993;189:531-5.

39. De Gregorio Ariza MA, Gamboa P, Gimeno MJ, et al. Percutaneous treatment of superior vena cava syndrome using metallic stents. Eur Radiol 2003;13:853-62.

\section{Take advantage of BMJ Journals' remarkable catalogue of titles with Related Collections}

No busy professional has time to browse through all pertinent journals to find relevant articles, but with Related Collections you no longer have to. Follow the "Related Collections" link from any article and use the "Show Collections from other Journals" to expand your search across all BMJ Journals. Or simply follow the "Browse by topic" link on the home page. By setting up your own collections and receiving email alerts every time an article is added to your chosen area, you can build up your own significant body of knowledge. 